\title{
The Role of Communities in Strengthening Social Capital of Coastal Communities through the Library
}

\author{
Putut Suharso ${ }^{1,2^{*}}$, Bani Sudardi ${ }^{1}$, Sahid Teguh Widodo ${ }^{1}$, Sri Kusumo Habsari ${ }^{1}$ \\ ${ }^{1}$ Postgraduate Program in Cultural Studies, Sebelas Maret University, Ir. Sutami No. 36A street, Surakarta 57126 Indonesia \\ ${ }^{2}$ Departement of Library Science, Diponegoro University, Prof. H. Soedarto SH street, Semarang 50275 Indonesia
}

\begin{abstract}
Library is a place that provides information openly and freely for the community. With the principle of openness, libraries can be accessed by all levels of society. The purpose of this study is to provide an analysis of the active role of some communities in establishing private libraries to provide information services to coastal communities. This research is a qualitative research with case study approach in coastal area of Semarang. The results of the research there are several libraries that were established by individual communities. Libraries are established using several terms; as; community reading park, reading house, smart garden. The management of libraries from self-help communities ranging from librarians, collections, buildings and infrastructure facilities. Activities undertaken by librarians have provided creative services to contribute to the literacy capabilities and social capital of coastal communities through a diverse collection of books that support social strengthening and entrepreneurship training.
\end{abstract}

Keywords: coastal communities; library services; social capital

\section{Introduction}

The library as a center of knowledge and learning center has a very important role in community development because it provides so much information that can be used by the community. The library provides information openly and freely to the public. With the principle of openness, libraries can be accessed by all levels of society when they intend to have skills that can be used to produce something of economic value, from simple products to sophisticated products [1]. Not only that, the library actually provides so much information and knowledge that can be used to solve the problems of daily life, from family health to information on how to broaden the community in society [2]. The library is a 'storehouse of knowledge', not a book warehouse as it has been perceived by people in general.

Indonesia's country is famous for its rich marine and coastal potential. This is in accordance with the designation of Indonesia as an archipelagic country. The potential of Indonesia's coastal resources is very wide ranging from potential biological resources, regional potential, mineral and energy resources potential, industrial potential, transportation potential and environmental services. With the islands scattered and vast oceans or large waters, then Indonesia has abundant fishery resources. The potential of fishery resources is potential to be developed. This policy orientation also involves strengthening the social capital of coastal communities. Therefore, the development of coastal and marine resources is expected to be an alternative and a source of new growth for sustainable development, especially coastal communities. One of the great potentials of Indonesia's biological resources is fisheries.

Central Bureau of Statistics noted that in March 2017 the number of poor people, the population with per capita expenditure per month under the Poverty Line) in Indonesia reached 27.77 million people (10.64 percent of the total population) [3]. From the results of a study by the Ministry of Fisheries and Marine Affairs (Kementerian Perikanan dan Kelautan $=$ KKP) in 2014, the number of poor people in Indonesia is dominated by residents in coastal areas. The number now reaches 7.9 million people or 25 percent of the total number of poor people in Indonesia [4].

Libraries are growing rapidly from time to time adjusting to the development of people's lifestyles, needs, knowledge and information technology. These developments also have an impact on the "grouping" of libraries based on these patterns of life, need, knowledge, and information technology. The terms libraries "swell" become very broad but tend to have a specific specification. From district libraries, village libraries, mosque libraries, private libraries, mobile libraries, and so forth.

\footnotetext{
*orresponding author: putut.suharso@gmail.com
} 


\section{Literature Review}

Management of coastal areas of Semarang city allegedly full of interests, especially from businessmen and institutions located in the coastal region of Semarang. On the other hand, so far, many parties have seen the problem of poverty only on the dose of seemingly external phenomena covering multi dimensions of political dimension, social dimension, economic dimension, and resource dimension or other [5]. The orientation of various poverty reduction programs that focus only on one dimension of the symptoms of poverty basically reflects the partial, sectoral, charity program approach and does not touch the root cause of poverty itself. The programs run are incapable of fostering community self-sufficiency that is finally unable to cultivate sustainable aspects.

Social capital is slightly different from other popular terms, namely human capital. In human capital everything more refers to the individual dimension of power and expertise possessed by an individual. In social capital in a library more emphasis on the potential groups and patterns of relationships between individuals in a group and between groups with space attention on social networks, norms, values, and beliefs between families born from members of the group and become a group norm in society [6,7]. In addition, social capital is also used to understand various other social problems.

Social capital has an important role in the functioning and strengthening of modern life [8]. It is seen from the understanding of social capital is believed to be an important component in mobilizing togetherness, the mobility of ideas, mutual trust and mutual benefit. Andreas Varheim [9] also adds that social capital in libraries is a community's ability to work together to achieve common goals within various groups and organizations. This common goal is related to prosperity, prosperity, success and others in community life on the coast. Some of these things will be easily achieved by a society if each other has a strong belief. The ability to cooperate arises from common beliefs within a society or in the smallest parts of society. Social capital can be institutionalized into the smallest group or in a large community group such as the state.

With regards to community empowerment, social capital can build relationships of individual strengths and abilities with a natural relief system and proactive behavior toward social policy and social change [10]. Community empowerment is oriented towards good improvement interventions, as long as they also have a goal of fixing problems, providing opportunities for their members or individuals to develop knowledge and skills, and engaging professionals who collaborate or cooperate in lieu of experts. Empowerment can not be separated from the participation of outsiders of the group as supporters and facilitators in gaining the power or empowerment of individuals in the community.

\section{Research Methods}

The purpose of this study is to provide an analysis of the active role of the community in participating in creating and developing libraries to provide information services to coastal communities. Research sites in the coastal city of Semarang in several libraries and parks read (Fig.1).

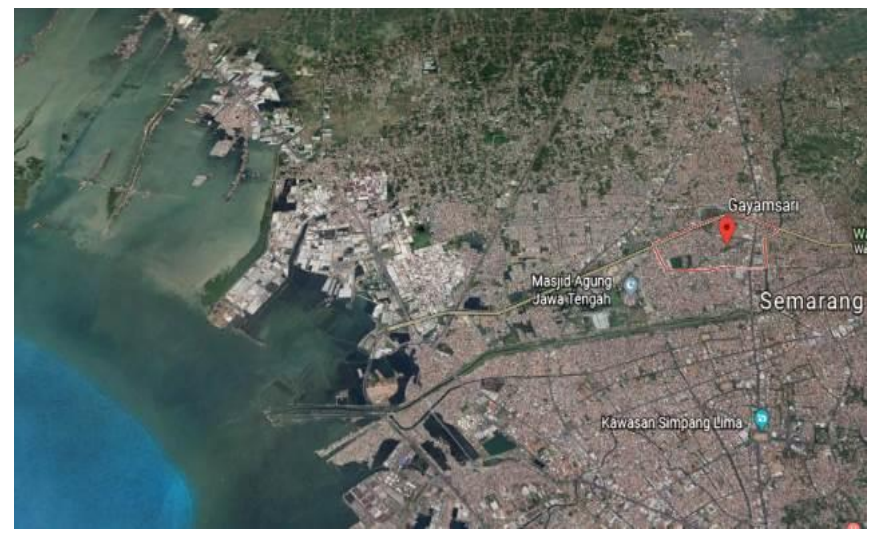

Source: https://maps.google.com/

Fig. 1. Map of research location in Semarang city

Qualitative research methods with ethnographic research approaches from socio-cultural phenomena [11-13] coastal communities, including observation activities, interviews and ethno-historical research or documents. Source of key informant data consisting of librarian, user and community. In testing validation by using data tranggulasi. Data is processed with descriptive explanation of phenomena and theory. 


\section{Result and Discussion}

\subsection{Development of coastal libraries}

Coastal region is a dynamic area that is very strategic to develop various business sectors. But unfortunately government empowerment programs by the government for coastal communities have not been worked out proportionally. So far, the supporting facilities in berkehidupan have not been fulfilled, especially related to non-formal education facilities. In this case the library becomes a tool that can be used by the coastal community in assisting the lack of access to education [14]. In the coastal area of Semarang city, now has grown various places with various names that are not using the name of the library, such as; Rumah Baca, Rumah Buku, Taman Baca, Taman Bacaan Masyarakat, Taman Pintar and others. When referring to the function given by the place it can be said as another name of the library.

The existence of various libraries that exist is dependent on the shade institution as a source of funds in developing the library, of all components. This dependence is indeed inevitable because the library holds the principle of being a nonprofit. This principle makes it impossible for libraries to be financially "reciprocated", which is mistakenly perceived as an 'unprofitable' institution and a fund-raising institution, whereas with the concept of regional autonomy, almost all institutions are required to efficiently generate financial revenues.

In terms of the existence of this library, the authors found several libraries that have been successful in running the operations of library services, without any shade institution. As Rumah Baca Seroja in Tambak Lorok, Taman Baca Asthabil is managed by Ninik Ambarwati in Genuk area, Pondok Baca Mortir in Banyumanik and others. The existence of the library has been supported by the government through the library of Semarang city by providing indirect assistance in running its activities. With the limitations that exist in the library level of the city of Semarang in providing services and assistance of the library so much, then the library service programs around the city library to be a solution. Although still less than optimal, because the schedule of visits only 1 time in two weeks, and many areas are still not formed this service.

Looking at the situation is now starting to move some social institutions that focus in the development of education through libraries such as community ASA Edu is a coastal social community, especially in Tambak Lorok region, is one of the community driving motors based on three pillars of education, creativity and health. In addition there is also Foundation Pondok Baca Rotary Indonesia is a foundation that gives attention to the development of reading interest for Indonesian children. The establishment of Pondok Baca is based on "Rotary International Program Focus Area" which one of them is engaged in "Literacy". In implementing the development and continuity of library activities in the city of Semarang, the community must be able to run independently of the library. From the managers there must be people who really moved in high social soul, because without salary must work social in society. So the role of community leaders and village government should be able to provide solutions.

Governmental policies in the field of socio-economic (education, health, economy, infrastructure and institutional) in the development of coastal communities that are "left behind" need to be re-engineered, especially those related to the provision of educational facilities in the form of libraries, because the development of coastal communities living as fishermen in the region the coast is very slow, most of whom are the poor.

\subsection{Library as a place of learning}

With a wealth of knowledge resources it has, the library is actually one of the main supporting factors for the government when it will implement the development program, both physically and mentally because through the library. Information on development policies can be disseminated to the community in a more effective way and reaching different layers of society, whether social, educational, age, ethnic, or economic. This can happen because in the library there is no distinction to visitors. Everyone is served according to his needs, not his status.

The existence of the library becomes part of civilization and human culture to lead to change in life. One of the goals of the independent Indonesian state to educate the nation's life. One of the learning tools that can be used in the intellectual life of the nation is the library. The role of libraries also bring a positive impact to the community, so it can form an information society. It can be seen how information the way people treat information, respect for information, how people seek information, how people need information. Especially now people should be more careful about the information that is hoax/fake that contains the provocation of news in the community, the development of social media through smartphones and news coverage on television is demanded by the community can select properly and utilize precisely also, now known as the term information literacy. 


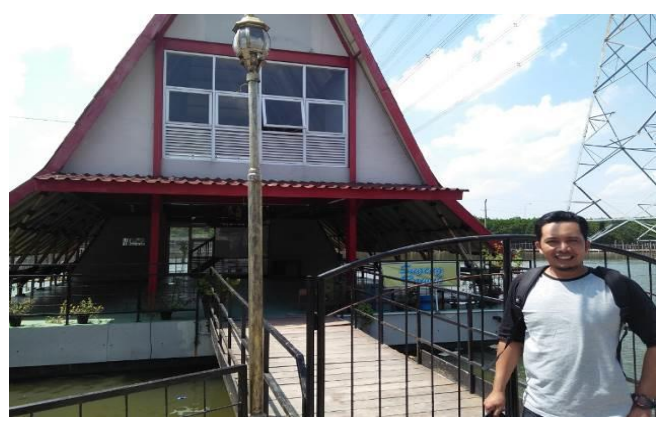

Fig. 2. Rumah Baca Apung in Tambak Lorok

Coastal communities in the city of Semarang have tried to provide library services innovatively, not only provide services in the form of book lending in the library. Those in the library can increase their knowledge of skills, and the talk of children is needed as a supporter of non-formal learning facilities after returning from school [15]. The existing libraries, in general, provide a space for open space that can be used for group discussions. As in the floating library of houses in Tambak Lorok (Fig.2) has floating buildings established by Ministry of Public Works and People's Housing which consists of 2 floors, first floor for meeting hall and discussion, second floor for book storage space, magazines and others as a library collection.

Other libraries such as Sri Redjeki Hartono Book House in Gayamsari area, which is originally a private library owned by a professor of law at the University of Diponegoro provide access to learning for the community in the surrounding environment. The spirit of library development has begun to be felt by the community. Moved from the lack of learning facilities in the community, so the emergence of a library that without the command can move naturally with the same vision of providing information services that are easy and free in the community.

\subsection{Diversity of library activity}

The result of the research is that there are several libraries established by individuals and community groups. Libraries are established using several terms; as; community reading park, reading house, smart garden. Management of libraries from non-governmental organizations from librarians, collections, and buildings and their means of prasananya. Activities undertaken by librarians have provided creative services to contribute to literacy skills.

The diversity of library services between one place and another there is no striking difference. A high level of creativity through an activity agenda beyond routine activities should be done. The demand for information from the community, coupled with open access to information in the community, becomes a challenge for library managers in providing services that can be sought by the community. Activities are conducted (Fig.3) in the afternoon until the afternoon after the children come home from school and for adults after they return from their regular work activities.

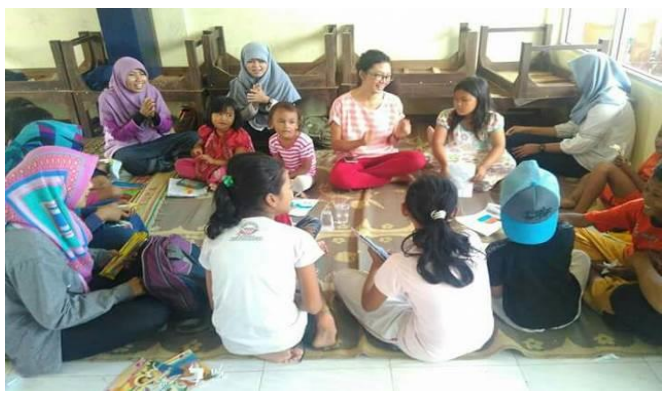

Fig. 3. Learning activities at Rumah Baca Seroja

Common examples of library activities include: reading together, watching inspirational films, presenting inspiring, storytelling, bulletin community activities, learning to write from authors, retelling books, theater, music, learning from the environment, surgery books, other and so on. Activities conducted by libraries are activities with the principles of the community and for the community. 


\subsection{Library as social capital}

The efforts undertaken by libraries in creating social capital in a coastal society is to build public trust, instill norms and values, and form a social network. The effort is manifested in the form of work programs and routine activities built by libraries, volunteers and other social institutions. In building the trust of the library community organizes activities where the community is involved in the effort to develop the capacity of the community. Starting from children's activities through art training, dancing (Fig.4), storytelling, introduction of environmental management and so forth. For the community where the library becomes a place to unite them through forums of socialization of several programs of activity by village government and community empowerment. The role of libraries as social capital of coastal communities through a diverse collection of books that support social empowerment and entrepreneurship training.

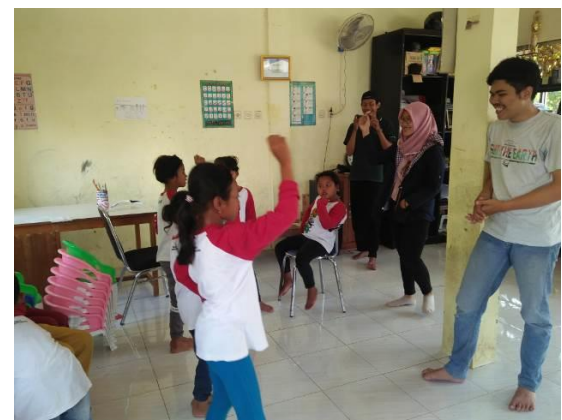

Fig. 4. Exercise dancing in by volunteers in the library

The ASA edu community through its volunteers provides guidance on school subjects, free of charge to school-age children in coastal areas. The accompaniment of Laskar Sedekah is also carried out for the less fortunate and orphans and / or orphans, and some other activities that integrate with existing programs in the library. For now the presence of institutions that can provide full support is expected by this literacy pengiat. When looking at the extent of the existence of the library with the diversity of its activities, the government should pay more attention to provide adequate funding, private sector should also have to enter through the CSR (Corporate Social Responsibility) program for education for these coastal communities.

\section{Conclusion}

The existence of libraries in the coastal area is now beginning to grow. Slowly but surely, the role of library akn seen by the community will be the importance of library functions. The community has an important role in managing the library independently so that it can survive and run the role of the library as a source of public information. The services provided by the librarian have started creatively to be able to turn this learning tool into social capital.

The authors would like to thank the literacy activists in the city of Semarang who have volunteered to develop libraries in coastal areas, especially for mas Udin in Tambak Lorok which has become a pioneer in the community mobilizer. I would also like to thank Prof. Sri Redjeki Hartono a professor of law at Diponegoro University who has made a private library into a library that can be accessed by the general public.

\section{References}

1. Durcan T 2011 The future of and for library and information services: a public library view Libraries and Society: Role, responsibility and future in an age of change ed D Baker and W Evans (Cambridge: Chandos Publishing)

2. Jochumsen H 2012 The four spaces - a new model for the public library New Libr. World $113586-97$

3. Central Bureau of Statistics 2017 Persentase Penduduk Miskin September 2017 Mencapai 10,12 persen (Jakarta: Central Bureau of Statistics)

4. Statistics C B of 2016 Marine and Fisheries Information (Informasi Kelautan dan Perikanan) Januari

5. Indarti I 2015 Coastal Resources Development Based Community Development Cooperation in the Coastal Fishermen Semarang Fokus Ekon. 10 44-61 
6. Hillenbrand C 2005 Public Libraries As Developers of Social Capital Australas. Public Libr. Inf. Serv. 18 4-12

7. Vårheim A 2014 Trust in Libraries and Trust in Most People; Social Capital Creation in the Public Library Libr. Q. Information, Community, Policy $84258-77$

8. Vårheim A 2008 Theoretical approaches on public libraries as places creating social capital World Library and Information Congress: 74th IFLA General Conference and Council (Québec, Canada) pp 1-13

9. Vårheim A, Steinmo S and Ide E 2008 Do libraries matter? Public libraries and the creation of social capital $J$. Doc. 64 877-92

10. Poeloengasih C D, Bardant T B, Rosyida V T, Maryana R and Wahono S K 2014 Coastal community empowerment in processing Kappaphycus alvarezii: a case study in Ceningan Island, Bali, Indonesia J. Appl. Phycol. 26 1539-46

11. Saukko P 2003 Doing Research in Cultural Studies: An introduction to classical and new methodological approaches (London: SAGE Publications)

12. Lincoln Y S 2002 Insights into library services and users from qualitative research Libr. Inf. Sci. Res. 24 3-16

13. Patton M Q 2015 Qualitative Research \& Evaluation Methods: Integrating Theory and Practice (California: SAGE Publications)

14. Suharso P, Sudardi B, Widodo S T and Habsari S K 2018 Library Development Strategy for The Community at Coastal Areas IOP Conf. Ser. Earth Environ. Sci. 11612002

15. Nurislaminingsih R 2017 Attitudes of fishermen in tambak lorok semarang towards library Adv. Sci. Lett. 23 $10042-4$ 